\title{
Critical events of the 1940 s in Estonian life histories
}

\author{
Tiiu Jaago \\ Department of Estonian and Comparative Folklore, University of Tartu \\ Ülikooli Str. 18, 50090 Tartu, Estonia \\ e-mail: tiiu.jaago@ut.ee
}

\begin{abstract}
The article observes how critical times, conditioned by events concurrent with Soviet power and World War II, are currently reflected in life histories of newly independent Estonia. Oral history analysis comprises texts from southern Läänemaa: oral life history interview (2005), written responses to the Estonian National Museum's questionnaire "The 1949 Deportation, Life as a Deportee" (1999) and a written life history sent to the Estonian Literary Museum's relevant competition "One Hundred Lives of a Century" (1999). Aiming at historic context, materials from the Estonian Historical Archives and Läänemaa County Archives have been used. The treatment focuses on two issues. First, whether oral and written narratives only differ by the form of presentation or do they also convey different messages (ideologies). Secondly, whether memories and history documents solely complement each other or do they more essentially alter the imaginations obtained from the events. The public is presented with experience narratives on coping under difficult circumstances, both at practical and mental levels. Narratives are presented from a certain standpoint, pursuant to narrators' convictions, with the main message remaining the same in different presentations. The addition of history sources enables to better observe the evolving of narrative tradition (narration rules) and highlight new questions (hidden in the narrative).
\end{abstract}

The history of 20th century Europe is characterised by the intervention of aggressive politics into everyday life. Regarding life history narratives, this brings about the interweaving of the narrator's personal life events with these of historical ones. Analogously, Alessandro Portelli, a researcher of Italian oral history, writes: "War keeps coming back in narratives and memories as the most dramatic point of encounter between the personal and public, between biography and history" 
(Portelli 1997: ix). At the same time, it is impossible to phrase absolute criteria to be used for deciding upon the criticality of a historical period, based on the personal narrative. The qualities attributed to the time are revealed in comparison with other "times".

\section{Research background: problems, subject matter, sources}

The current article focuses on the depiction of the 1940s in Estonian life history narratives, ${ }^{1}$ where the subject matters gyre around the imposing of Soviet power, events of World War II and repressions. Criteria of criticality in these narratives comprise extreme situations in personal life associated with political changes, expressed in conflicts between personal wishes and forced choices, and also in the loss of close people and one's home, deportation, imprisonment and interrogation situations. Currently, the "post-war years are being prevailingly described through traumatic experience" conveyed by the mentality of the pre-war time (i.e. the time of independent Estonia) (Hinrikus 2003: 198). The critical nature of this period is being experienced not only as personal but concerning the fate of the whole nation. However, when adding the Russian-language narratives to the Estonian ones, it becomes evident that different ethnic groups in Estonia may sporadically perceive and interpret the events of the 1940s in a contradictory manner (Jaago 2004: 179-181).

Why do Estonian narrators focus on the critical period of the 1940s? Rutt Hinrikus (2003) highlights a couple of important aspects. First, the suitability of dramatic events for the creation of narratives as

the history of dramatic experiences mostly contains a complete story, including the exposition as well as culmination(s) and exotic details which are never existent in peaceful and monotonous everyday life. (Hinrikus 2003: 191)

To this, Hinrikus adds a psychological need to reminisce. In addition to the above-mentioned, I emphasise the impact of the quality regarding the time of narration on the choices as to what periods of

\footnotetext{
Regarding the research on Estonian life history narratives, see Kirss et al. 2004.
} 
history people prefer to talk about. ${ }^{2}$ The 1990 s were a pivotal period in Estonia where history was rendered rethought from a new standpoint. Historic events of the 20th century have offered plenty of opportunities to experience that relationships between people do change on the boundary of stable and critical times. This has induced discussion on behavioural preferences and norms, by way of analysing concrete situations. The subject matters, referring to analogous earlier situations, become actualised in the framework of the discussions.

The narrators of the life stories used in the article were born in the 1920s. Their childhood passed in a stable society. By the dawn of pivotal times in 1940 they had become adolescents. Their parents, born at the beginning of the century, had been in contact, to a smaller a greater extent, with revolutions and wars. ${ }^{3}$ The grandparents of the narrators had lived in the "tsarist time" (also "manor time", "serfdom time"), revealed in the narratives by way of social confrontations rather than those deriving from power conflicts. The experiences, obtained within the family and kinship relationships, are amalgamated in the narratives regarding the 1940s, intermittently in opposing and supportive ways.

All the analysed life history narratives originate from the same area in West-Estonia. The examples have been received by three different archives during 1999-2005. Firstly, author's fieldwork materials located in the Department of Estonian and Comparative Folklore of the University of Tartu. Secondly, the written life history narratives in the Estonian Literary Museum. ${ }^{4}$ The third source comprises the written responses to the thematic questionnaires compiled in the Estonian National Museum. ${ }^{5}$ Upon creating the context, history documents from the Estonian Historical Archives and the Läänemaa County Archives have been used.

\footnotetext{
2 The prerequisite for narration is the existence of the impetuses for remembrance (Tulving 1994: 68). Real life stories are being designed proceeding from the time and goals of narrating: although the events remain to be what they were, they are attributed certain meanings during the narration process, proceeding from the time of narrating and the impetuses of remembering.

1905-1907 and 1917 revolutions, World War I 1914-1918, War of Independence 1918-1920.

4 Regarding "Estonian Life Histories" collection, see Hinrikus, Kõresaar 2004.

5 (Electronically published) questionnaires of the Estonian National Museum: www.erm.ee/?lang=EST\&node=58.
} 


\section{Tiiu Jaago}

The following treatment has proceeded from oral history-related research opportunities. In Estonian research tradition, I refer to this domain as popular narrated history (pärimuslik ajalugu), which, in its wider sense, is related to oral history. ${ }^{6}$ Popular narrated history is a research direction that was developed in Estonian folkloristics in the 1990s, relying, on one hand, on the internal renegeration of the particular discipline since the 1970s and, on the other hand, on the change of society at the end of the century. Within the science, this primarily means an interest in contemporary folklore which positioned itself next to the research of classical types (these of the past) of folklore (e.g., the works by Linda Dégh, Jan Harold Brunvand, Bengt Klintberg and Leea Virtanen; in Estonia, the works by Mare Kõiva and Eda Kalmre). At the same time, the disciplines of humanities and social sciences were converging, incl. the highlighting of interdisciplinarity in the 1990s (cf. Brednich 1998 [1990]: 8-13; Thompson 2000: xi-xii). In Estonian folkloristics, this purported delving into the research method proceeding from the folklore group, counterbalancing the text-centred research of folklore, predominant in Soviet folkloristics (cf. Ivanova 1994). In the case of the latter, it was preferably the opportunities of literary science that were utilised or instead, folklore was primarily related to literary texts - this is also characteristic of the analysis of texts that reflect real-life events, as, for instance, the treatment on the songs and folk narratives of the 18771878 Russian-Turkish War (Rüütel 1977; Hiiemäe 2000 [1977]) or that of the revolutionary songs (Tampere 1970).

Side by side with the developments inside the scientific discipline itself, the elaboration regarding the research method of narrated history was also affected by historical-political developments in society (first and foremost, the collapse of the Soviet Union) which activated the disputes on various treatments of the past. The research of narrated history, evolved in the 1990s in Estonia, has indeed been servicing the ascertaining of different interpretations of the past. Nevertheless, this is not a discipline of history (differently from oral history) as the study of narrated history proceeds from narrating, intrinsic of folk tradition, and methods of folkloristics. The "route" of oral history is just the opposite: when creating the source of

6 For comparative research overview of oral history (popular narrated history) in Estonia, Finland, Latvia and northeast Russia, see online folkloristics journal ELORE 1/2006, http://cc.joensuu.fi/ loristi. 
research - oral history interview - it is the events of history that are the starting points, and, as a rule, the interviewer as one of the creators of oral history is a historian by profession (Grele 2000 [1998]: 42-43).

The researcher of narrated history does not focus on the classical history-related question as to "what happened" but instead, on how the narrator, in his or her story, presents the impact of the past events and situations on the period of time that remains between the narrated event and the time of narrating. ${ }^{7}$ At the same time, folkloristics has been determinedly studying the connections between the real-life based narratives with the stories existing prior to the event - folk tradition, i.e. the narrative is created as an outcome of cooperation between real life experience and the existent means of expression (narrative tradition) (see, e.g., Hiiemäe 1978: 62-67; Nekljudov 1998).

The connection between history and folklore has been obvious from the very beginning of this branch of science. Regarding the development of this relationship, Peter Burke differentiates between three stages: the age of harmony (1846-1920s) characterised by "popular antiquities", one of the denominations of folklore, establishment of (national) museums and dealing with the domains official history was not paying attention to (such subject matters as the state and religion); the age of suspicion (1920s-1970s), characterised by the sharpening of the boundaries between the disciplines of science and also the specialisation of research branches; and the age of rapprochement (since the 1970s), exemplified by interest towards local history, popular culture and the so-called "history from below" in the disciplines of history, and, in folkloristics, towards socio-cultural processes (Burke 2004; cf. Thompson 2000 [1978]: 71-81). According to the periodisation by Burke, it is possible to see the following events in Estonia. In the middle of the 19th century, Friedrich Reinhold Kreutzwald wrote about historical legend as one of many possible sources to study the past (Kreutzwald 1844). History "through the eyes of the people" was also the principal idea of the folklore programme for Jakob Hurt, the organiser of large-scale folklore collections, whereas in the sense of "folklore", he used the concept "folk memories" (cf. the above-mentioned "popular anti-

\footnotetext{
Regarding the unity of the past, present and future time in folklore texts, see, e.g. Gerndt 1986 [1981]: 38.
} 
quities") (Jaago 2005: 46-52). This direction of folklore research became topical again in the 1920s and 1930s, but really, differently from contemporary study the approach described above was discipline-centred (Jaago 2002).

The study of narrated history, or folkloristics oral history in Estonia, is characterised by simultaneous use of different types of sources: both oral interviews as well as written recordings thereof, written thematic narratives which in turn were created both spontaneously (for one's own family and descendants) and as responses to the calls by archives (Estonian Literary Museum, Estonian National Museum, National Archives of Estonia). Regarding the study of narrated history, preference is given to the narratives where the participation of the researcher (interviewer) is minimal. In addition to this, classical history documents and other public texts (research on history, media texts, school textbooks) are being used. Indeed, the study does proceed from the narrative, however, one source is not preferred to another: the issue is in the comparison of different viewpoints and angles, rather than finding the so-called truth. The narrator's viewpoint is positioned in a relationship with other texts and the results are analysed within the historical context in order to ask as to why the studied narrative (or a viewpoint) could be namely the way it is. For instance, the study of kinship history by way of mutually comparing the family folklore and documents of history, the aim of which, differently from genealogy, is not to ascertain the "proper" history but rather in finding the social and cultural factors that affect the emergence and evolving of knowledge existent in family folklore (Jaago, Jaago 1996).

In the current article the focus is on two issues. First, whether oral and written narratives only differ by the form of presentation or do they also convey different messages (ideologies ${ }^{8}$ ). Secondly, whether the sources from different archives solely complement each other or do they alter the imaginations obtained from the events in a more essential manner. Both the above-mentioned main issues are in turn permeated by an axis: how are the time of the events and the time of narration interrelated?

8 In Estonian life history research, Ene Kõresaar (2005) uses the concept "ideology of life" so as to describe the system and logic of narrators' interpretation of the past. 


\section{"Confluence of times": reality, remembering and narrating}

In the following subsection, I will introduce the two somewhat contradictory opportunities for depicting the coherence of times within an interview. Firstly, how are the flows of times being related in a narrative once the earlier "times" start to reduce in the memory? Secondly, how, due to the similarity of personal life experience and that of the parents, are relevant "times" also being related in the narrative?

Recording of the interview in question took place in connection with a more lengthy work when I was looking for data about Madli Kindel, a folk singer from Läänemaa. Her songs had been written down in 1889. Differently from other folk singers whose song texts were written down at the time, there was no genealogical data available about her in the Historical Archives. The reason for dealing with this subject matter proceeded from the research on the socioeconomic context of the persistence and alteration of Estonian old folk song tradition. In summer 2005, I went to the villages where the studied folk songs had been written down. During the past 117 years, the consistency of settlement had significantly altered and I did not expect to find the descendants of the then folk singers. Nevertheless: Jaan Kindel was one of the indigenous inhabitants in the locality - he had the same family name as the singer I was interested in and I asked him whether he knew Madli. The man responded: "Yes, Madli is my grandmother. She was so old that she even wasn't deported!"” Such a reply surprised me for two reasons: on one hand, consistency of the folk singer's family indeed existed in the same locality (true, in a neighbouring village). On the other hand, the second half of the sentence - "she was so old that she even wasn't deported". Deportation is the subject matter which is abundantly talked about both now as well as during this fieldwork to southern Läänemaa in August 2005. ${ }^{10}$ Tape recording of the conversation with Jaan Kindel and his wife Laine also twists around the issue of deportation,

9 On March 25, 1949, approximately 23,000 inhabitants were sent from Estonia to Russia by the Soviet power (Rahi 2004: II 16). Narrator's grandmother Madli Kindel (b. 1861) is in the list of those to be deported, however, with a note "not deported" (Õispuu 1999: 188).

10 Fieldwork materials are located in the Department of Estonian and Comparative Folklore, University of Tartu (MK: Läänemaa 2005). 
although my questions were related to family and genealogical history.

Jaan talked about the origin of his grandmother. When comparing the obtained oral data with the documents of the Historical Archives, it became evident that what I heard from Jaan about his grandmother Madli was actually partially associated with Madli's parents: in the family history narrative, the time of two generations had merged into one. When I asked whether Jaan remembered his grandmother's stories and songs, he said his grandmother used to talk about hard work for the landlord. This is intrinsic of family tradition to know the 19th century by way of narratives on hard physical labour. The 20th century narratives, on the other hand, turn around the impact of political events. In family narratives, these periods are revealed as times with a different quality, offering the then and current narrators a whole spectrum of totally different experiences. In 1949, Jaan Kindel was taken to Siberia from his ancestors' farm and he could not return to his home any more. "My father's home was rebuilt into a kolkhoz grain drier, working at full speed: Thus my family could not stay there," Jaan described the situation when he returned from deportation in $1959 .{ }^{12}$ The narrator distances himself from his ancestors due to the difference in life experience and the loss of their common home. "Confluence of times" in the narrative is connected to the dispersion of facts as what has been heard from the older generations has become passive tradition.

The next example from the same interview, however, discloses a contradictory tendency: experiential narrative heard from parents becomes actualised due to reoccurrence of a similar situation. Conversation continued to focus on kinship and family history, with the narratives reaching the time of World War I (1914-1918). Jaan described this period by way of hard work and lack of food. His wife Laine took over with a phrase "yes, the times were very difficult also for our family". She talked about the war-time hunger experience of her mother and aunt: eating brick crumbles; finishing the jar of honey meant for the mother in her sickbed: children knew that is was forbidden, but they were so hungry. These are episodes with wellelaborated imagery language where difficulties conditioned by historic

11 Recording is in the Department of Estonian and Comparative Folklore, University of Tartu (MK: Läänemaa 2005, CD-2).

12 Estonian National Museum (ERM), KV 874, p. 188 (1999). 
events (children's hunger), family destinies (heavy illness of the mother of children) and characters (strict father but still capable of understanding children) become intertwined. Suddenly the narrator's voice broke. She made pauses to keep back the tears, said single phrases: "it was a difficult time...", "that's what mother used to say...", "it was as if in Siberia...", "mother and I were eating couch grass...", "there was nothing to eat..." These couple of phrases reveal that narratives about World War I had become actualised after 1949 when she had and her mother had been taken to Siberia. During the interview, she, surprisingly to herself, associated these real-life episodes by way of the similarity of emotional "charges", jumping the gap of more than three decades between the chronological sequence of the events. Still, these associations had to be existent during earlier narration situations: as she mentions "that's what mother used to say".

Such a temporary loss of control in the narrator, which in turn evoked stronger empathy in me as a listener, induced the question as to why the presentation of the hunger-topic differed from the way of presenting other subject matters. I analysed this nearly 40-minuteslong interview, inspired by the treatment of Alessandro Portelli, researcher of oral history (2000 [1991]: 65-66). According to this method an oral text is being interpreted by considering the reciprocal harmony of the narrative (subject matters, transfers from one topic to another, etc.) and the features of the rhythm of speech and voice (tone, speed, etc.). The analysis revealed that Laine was telling a story of coping, presented from the standpoint of the outcome. What came in the forefront were the summaries which at first sight remained in the shade of the event-related narratives but in the end remarkably shaped the messages regarding the very events of the critical time:

We've been burnt down once and we have wandered about and we've been abroad and... we've been all around. We've started from scratch and we haven't been naked either and have always had bread on the table... and we've raised and schooled four children ... So it's not been too bad. We have always coped.

The critical time in Laine's life history narrative as the rupture (see Kõresaar 2005: 69) of naturally ongoing life starts with her father's imprisonment in 1945 and ends in 1959 when she returns to Estonia with her family, after ten years of deportation. She summarises the time between her father's arrest and the deportation of the family 
(1945-1949) as "constant harassment was going on". To her knowledge, the "category" (i.e. reason) for her being deported is as follows: "Germans' henchmen" imprisonment and deportation are generally not given in the life history narratives of Estonians. How were the accusations being perceived and how were they justified by the Soviet power will probably be one of the subject matters for future research. ${ }^{1}$

Both Jaan and Laine describe the moments of deportation by focusing on the events rather than feelings. Laine mentions that at the night of deportation her mother could not stay calm and her younger sister was "small, slim, only in the fifth form". Laine was the one who packed the things at the presence of gunmen because "I already knew what life was about". As a background to this knowledge she talks about the norms in forest work, established by the Soviet power, that she, a 19-year-old girl had to fulfil. She talks about the difficulties (cold, lack of tools, distance of the residence from the work site, wet clothes that could not be dried for the next workday etc.) and also about the measures to attempt to solve the situation (hints to cooperation with fellow sufferers). She talks about the threatening: if the norms are not fulfilled, the future would be Siberia or prison. She fell severely ill. The episode which started with the claim "I already knew what life was about" she concludes with the statement of the time: "as far as I'm concerned, they [Soviet authorities] can send me to Siberia or another Siberia or kill me right here, I will not go back there [in the forest] any more". She did not touch upon the starvation experience during deportation narratives within this conversation.

\footnotetext{
13 Indeed, I came across such a definition, "Germans' henchmen", in 1945, in the lists of "people's enemies" compiled by Soviet power representatives (LMA198-1-15), but soon it was replaced by an expression "Germans' myrmidons". During the Soviet time, it was quite difficult to avoid being listed under this category within the territories that had been under the German occupation.

14 In 1989, the Estonian Heritage Society collected data on the destiny of arrested and deported persons, by way of a questionnaire. The respondents consistently mention that the reasons for imprisonment and deportation remained unclear for them. For instance "were taken away without court ruling, my husband was in prison and I was taken away with two underage children. Those who took us away were men in military uniforms" (f born in 1918. Materials in the Läänemaa Museum: Memory, 1989). The Soviet authority's standpoint could be researched after the collapse of the Soviet Union when access was opened to the archives of Soviet power institutions (see Mandel 2005).
} 
Has Laine presented different descriptions regarding starvation experience? During our conversation, she mentioned that she had sent her narrative on her deportee-life to the Estonian National Museum. Indeed, the Museum has her responses to the questionnaire, compiled by researchers, on the following subject matter "The Deportation of 1949, Life as a Deportee". 15 The questionnaire focuses on the events and situations. Some questions also target the situation with food and hunger. Laine responds laconically, however, providing abundant information:

Food was very bad before we got land (later we got more land, ten hundredth, 1955). There was no bread, not even for those who went to work. We picked nettle and orach leaves (at cattle barns, they were more lushy there, growing on piles of manure). We chopped them, boiled with water and salt and ate. In 1953, the kolkhoz gave $9 \mathrm{~kg}$ of rye flour per family (irrespective of the size of the family, imagine this!). We also ate edible flower bulbs and other edible plants that we searched for in the steppe. Malnutrition was horrible! (ERM, KV 874, p. 165)

At the end of her writing, additionally to the responses to the questions presented by researchers, she once again returns to this subject matter: she expresses gratitude to an old woman with whom they were living in the village to where they were deported. It was namely this old woman who had taught them to eat all kinds of plants.

Laine's mode of presentation is subject to narration goals and situations. The framework of the narration creates room for variation (written responses to the questionnaire; interview situation, etc.). At the same time, she has a distinct repository of core narratives and a well-established system of assessments, which become evident in all of her presentations.

\section{Events in the narrative and history}

In the following subsection I focus on the other facet of the problem: when the time (situation) of narration intermingles in itself the actual time of narration and the layers of earlier narrations, then how is it possible to separate the earlier time layers from the narratives? In

15 ERM, KV 874, pp. 156-170 (1999). 
order to achieve this goal, I will again use different types of sources. The analysed example is based on Lembitu Varblane's narrative. ${ }^{16}$ Similarly to Jaan and Laine Kindel, he comes from the same region in southern Läänemaa. Parallel sources comprise the minutes of the local authority meetings from 1944 to 1950, located in the Läänemaa County Archives in Haapsalu. The focus is on the depiction of postwar village life: in autumn 1944, warfare again reached Estonian soil. In places reached by the Red Army, Soviet power was established, and new life commenced with reorganisations, incl. the compilation of the lists of the so-called kulaks and Germans' myrmidons, accompanied by imprisonments and culminating in the large-scale deportation on March 25, 1949.

The narrator was recruited in the German army in 1943 (at that time, there was German occupation in Estonia). He managed to evade this by escaping to Finland where he served in the Finnish army. This, in turn, was a fact that had to be hidden from the new, Soviet power. In the following quote, there is an episode he was to face when returning home from Finland:

I reached home during the early hours of 23 September [1944]. There were tears of joy when meeting my mother and also the concern, sadness and enormous unknowing. My mother knew nothing about my father and brother. My brother had managed to escape safe and sound from the Lihula Self-Defence unit's ${ }^{17}$ battle against Russians at Kärevere bridge, had come home in the meantime and then was taken away again. What kind of Self-Defence tasks did my father fulfil and where he was, my mother didn't know. To extinguish my hunger, I was given proper farm bread and milk. I couldn't wish for more. I wouldn't talk about my feelings about home-made bread. Dead tired, I fell in bed in order to rest a little. I felt terribly sorry to leave my mother alone. (KM, EKLA f 350: 921, p. 10)

This relatively squeezed description reveals the confusion at the private level, intrinsic of the end-of-the-war times: no knowledge about the destiny of the father and brother, hunger, food-related sensations, tiredness, empathy towards mother. Facts and feelings are densely intertwined. The stability, having been achieved step by step,

16 Estonian Literary Museum (KM), EKLA f 350: 921. Lembitu Varblane has sent his written life history narrative to the relevant competition of "One Hundred Lives of a Century" (1999).

17 Local police units, consisting of civilians, which operated during war-time. 
is described in a more hinted manner, by way of adding a discussing summary:

In autumn 1948, my brother Vambola came home from war imprisonment. Somehow we managed to pay the increased norms and taxes imposed on the farm. Even my mother regained her mental balance. Both sons were safe and sound! We had to live on and worry less. The turns of Stalinist dictatorship could not be predicted. (KM, EKLA f 350: 921, p. 12)

Going back to the documents of the time, one can only imagine how complicated was this period (1944-1948) in reality. In March 1945, the local authority has already compiled a list of those referred to as kulaks and Germans' myrmidons. Regarding the village where the narrator of the above-quoted story comes from, there were four people in such a list, including the narrator's mother. ${ }^{18}$ These lists were not easy to be compiled neither for local inhabitants nor for authorities. Among the documents of the Läänemaa County Archives, there is an official reply to an official accusation as to why are there "only eight kulaks" in the rural municipality (the response is dated December 16, 1947). ${ }^{19}$ This letter reflects the conflict between the representatives of power, recruited from among the local population, and those representatives of power who had arrived from elsewhere: local people know each other and therefore the attempt to "find" kulaks was not successful. The reply evidences that the situation is becoming "better" - the list already comprises 34 kulaks.

Who occurred to be in the list of kulaks? Jüri Kindel has, e.g. worded this in his response to the Estonian National Museum's questionnaire "Post-war village" as follows: there were five kulaktype farms in my home village. The farms were "blamed for" the following: "excellent farm and breeding animals", "threshing machine and newly cultivated lands", "Saaremaa-type post-windmill, threshing machine and a well-kept 40 ha farm", "Dutch-type windmill and wellkept lands and household" (this refers to his parents' home), "excellent smithy and large newly cultivated fields". ${ }^{20}$ When reading the minutes of the local authority from 1944 to 1950, consolidated into a file titled "Agriculture", it turns out that in the given municipality,

18 Läänemaa County Archives LMA-198-1-15, pp. 5-6.

19 LMA 198-1-66.

20 ERM, KV 901, p. 53 (2000). 
two major groups of inhabitants were considered to be the enemies of Soviet power: "kulaks" (the list of kulaks seemed to be supplemented by those who had used farmhands or servants in their farms prior to 1944, despite the fact that these servants and farmhands had not filed any complaints) and the "myrmidons of Germans" (whose relatives had served in the German army or in other way had themselves fought against Soviet power). Who is who, these were constant discussions, testimonies, accusations, contra-statements - during 1944-1949, people had to suffer enormous pressure in their daily life. Some were forced to give statements, some to justify themselves. In addition, land reform was conducted at the time, referred to by norms and excessive tax burden imposed on farms within the above-discussed narratives. (Forest work experience in Laine Kindel's narrative; in Lembitu Varblane's story: "Somehow we managed to pay the increased norms and taxes imposed on the farm".) Regarding the entire period, there are only a couple of sentences in the narrative: "We had to live on and worry less. The turns of Stalinist dictatorship could not be predicted." In general, people claim they had no idea about their possible future by any other means than rumours or hunches. Likewise, Jaan and Laine Kindel state the same. ${ }^{21}$ Archive materials, however, show that such lists were compiled, discussed and disputed also at the local level.

Reading the minutes in the file "Agriculture" was a far more terrible experience for me than reading and listening to the narratives on this period. It can be stated that the depiction of such a reality is generally not a subject matter for narratives. There could be different reasons for this, e.g. the fact that the situation came to a solution in 1949 in connection with deportation and formation of kolkhozes. In narratives, they are topical as dominant events which indeed provided another direction to the course of life in the future. Undoubtedly, also the fact that these times are full of inconveniences, secrets and other issues that people would rather like to forget. There is no more lengthy contemplation on these people and themes.

People know the worst side of the daily life of the critical period, and that of their social group, however, they would not narrate about these issues but instead, mention the statements that have become the words of wisdom. In Lembitu Varblane's narrative, there are

21 ERM, KV 874, p. 156; p. 180 (1999). 
numerous hints to unwritten rules for behaving in a critical situation and also to relevant violations. For instance:

The situation in the fronts became more difficult every day. I decided not to go to the German army. I was hiding myself and worked in my aunt's farm. In the village, they knew who I was but a sensible rural family would not poke its nose into the issues of anther family. ${ }^{22}$ (KM, EKLA f 350: 921, p. 2)

The narrator provides a contrary example of an episode where he returns from Finland - in the port of Tallinn, there is a German patrol checking his documents. He produces the papers of a Finnish navyman but one faithful Estonian-speaking gendarme had understood from his name that he was an Estonian, and consequently, evading the German army, and thus the narrator was put into the Pagari Street prison. $^{23}$

The issue of intra-family relationships may also become lost in the descriptions of the critical time. For instance, in the above-described story, the narrator, when describing the deportation day (March 25, 1949) presents contemplation of the time: what else could this family expect if their "father [had] been sentenced to prison by the tribunal, as the enemy of Soviet power, and had died there." The father is mentioned once more when the narrator himself has been arrested and he described the interrogations where his father is being referred to as the enemy of Soviet power. When was the father imprisoned? ${ }^{24}$ When did he die? How did they learn about this? Was it already known in 1949 (the way the narrator presents it in his story, by uniting his knowledge of his father's death and the deporting of her mother, 50 years after the described event) or did they actually learn about this (father's death) later? If in the pre-war description, the father is depicted as a relatively concrete character, then after the war, the father disappears from the narrative, even at the level of mentioning

\footnotetext{
22 Here and in the following example, emphasis by T. J.

23 KM, EKLA f 350: 921, p. 9.
}

24 Pursuant to the published list of arrested persons (Õispuu 1998: 568) Jaan Varblane was arrested on November 28, 1944; the tribunal charged him guilty on March 14, 1945, pursuant to $\S 58$-1a (ten years in prison plus 5 years as a deportee). However, nothing is said about the future destiny. According to a historian Aigi Rahi (2004: II 9), during 1944-1945, approximately 10,000 men were arrested due to political reasons, "half of them died within the first two years". 
the facts. When reading the minutes of the local authority meeting, dated from April 9, 1948, where once again, there is a discussion whether the narrator's mother should be declared the "myrmidon of Germans", due to her husband's activity, it turns out as if the spouses had been quarrelling and separated in 1942, where-after family ties had been broken. ${ }^{25} \mathrm{~A}$ decision follows: as the spouses were not living together during the German occupation, it is not necessary to consider the wife's household as "the household of the Germans' myrmidons". (Despite this she was deported on March 25, 1949.) Such a consideration could have been either a partial or full self-protection. The husband had already been arrested (or even dead), it was impossible to protect him, however, it was still possible to protect the remaining members of the family. The narrative also comprises the tactics used at interrogation (March 1949):

Concerning my biography, I repeated what had been written down in the questionnaire and the CV. They were particularly interested as to who I was hiding at in Pirita. I knew that this men had fled to the West, that's why I could make up more lengthy things out about my life. (KM, EKLA f 350: 921, p. 15.)

The impact of critical times on people's course of life becomes predominant in narratives. In the newly independent Estonia, deportation and life as a deportee are public themes, similarly to the serving in different armies. Changes in family relationships in a historically critical era, and particularly the issues regarding interrogations and informers are of marginal relevance in the public or totally absent in the narratives. However, I have heard this privately (in the family and close circle) since my childhood.

For the current treatment, only one layer (the depiction of the critical time) has been chosen from Lembitu Varblane's 19-page-long life history narrative, being limited within one theme (post-war life in Estonian village). At this level, it is intrinsic of the built-up of the narrative to describe the events, assess the situation from one's own standpoint and decide as to how to cope. The latter also involves the valuing of wisdom based on earlier life experience. For instance, the summary of the situation and an advice from a great-uncle "who had suffered a lot during his young age". "David won Goliath with 
cleverness, don't do anything thoughtless! Stay calm and see what's going on." 26 Similar experience to behave exactly in such a manner, during the post-war critical times, can be found in different wordings, which means - this is a more general understanding than only presenting a standpoint of a single family or a man. ${ }^{27} \mathrm{I}$ have interpreted this life history narrative as an experience narrative which unites personal experience and that of the others into a uniform wisdom.

\section{In conclusion}

Using the example of three narrators, the article dealt with the depiction of critical times in a post-World War II village in WestEstonia. The depiction of the 1940s consolidated earlier family history and the later destiny of the narrators. The coherence of times in narratives refers to tradition-based perception of time, and specifically, to the quality attributed to the time. Times with similar qualities rely on each other, and thus become actualised over and over again. The knowledge, about times that differ from the narrator's own experience, moves to the more passive side of the tradition.

The ideology regarding the narratives of critical times is one and the same, irrespective of the fact whether the story has been immediately told to listeners, presented as a written response to questions or created as a free-structured written narrative. The narratives proceed from the narrator's point of view and his or her convictions which have evolved during a longer time period and are now, as an analysed text, one of the outcomes of the tradition. Current sociohistoric background in Estonia created preconditions for the selection of certain themes. During the post-Soviet time, the themes regarding arrests, deportations and the serving in different armies have become public. By way of this, the knowledge on the size and the boundaries of the 'our-group' is becoming more thorough, and relates to the issues concerning the moulding and designing of identity in society. In

\footnotetext{
26 KM, EKLA f 350: 921, p. 11.

27 E.g., one of the narrators from Saaremaa says the following about what he had heard in his village: you can't always get a medal and solve situations with a lot of noise... "Living between big nations, we could have been milled into powder a long time ago if we hadn't had the skills to manage our things little by little under each emperor." (KM, EKLA f 350: 1809)
} 
narratives, the focus is on one's decisions and behaviour within the framework prescribed by history. The subject matter regarding collaboration with the totalitarian occupation authorities (informers) is only hinted at, whereas the intra-family relationships-related topic "loses grip". The latter is undoubtedly conditioned by the lack of interest and even knowledge regarding the destiny of the close ones, a phenomenon intrinsic of the 1950s. At that time, it was impolite to ask strangers (e.g., schoolmates) about their origin or anything concerning their personal life. This domain was associated with the experience of the 1940s repressions, but could also affect the life of people towards an undesirable direction, during the entire Soviet period.

Discussions have been held whether memoirs are a reliable source for the research of the past. The same way, we could ask whether the NKVD materials are reliable. What kinds of tactics were used by Soviet functionaries to get testimonies? What kinds of tactics were used by those being interrogated? Regarding the standpoint of the current research, the issue of the reliability of facts is not of greatest relevance. Within the extent of the observed materials, the truths of the narratives did not become doubtful in the light of history documents, nor vice versa. Comparison of memories and archive materials offers intermittent alteration of distant and close-up views, enabling the observation of certain narration rules, as, for instance, the confluence of times, conditioned by forgetting in Jaan Kindel's narrative, actualisation of the theme in Laine Kindel's narration, and the screening out of wisdom in Lembitu Varblane's narrative. Juxtaposition of archive materials and narratives may indeed emerge questions (as in the case of Lembitu Varblane's mother and father), but this would not alter the perception regarding the events. ${ }^{28}$

28 Research for this article was funded by the project "Aspects of Terminology and Source Criticism in the Study of Everyday Culture" under the national programme "Estonian Language and National Memory"; the European Union through the European Regional Development Fund; targeted financed projects "Folklore and Society: Tradition, Memory, Creativity, Applications". Translated by Mall Leman. 


\section{References}

ERM, KV - Estonian National Museum

KM, EKLA - Estonian Literary Museum

LMA - Läänemaa County Archives

MK - Department of Estonian and Comparative Folklore, University of Tartu

Brednich, Rolf Wilhelm 1998. Die Spinne in der Yucca-Palme. Sagenhafte Geschichten von heute. München: Beck.

Burke, Peter 2004. History and Folklore: A Historiographical Survey. Folklore 115: 133-139.

Gerndt, Helge 1986. Kultur als Forschungsfeld. Über Volkskundliches Denken und Arbeit. (Münchener Beiträge zur Vokskunde 5.) München: Münchener Vereinigung für Volkskunde.

Grele, Ronald J. 2000. Movement without aim: Methodological and theoretical problems in oral history. In: Perks, Robert; Thomson, Alistar (eds.), The Oral History Reader. London: Routledge, 38-52.

Hiiemäe, Mall 1978. Kodavere pajatused. Kujunemine ja koht rahvajututraditsioonis. [Die Alltagsgeschichten von Kodavere: ihre Entstehung, Entwicklung und Rolle in der volkserzählerischen Tradition.] Tallinn: Eesti Raamat.

— 2000 [1977]. Vene-Türgi sõda eesti rahvajuttudes. In: Hiiemäe, Mall, Sõnajalg jaaniööl. Tartu: Ilmamaa, 101-112.

Hinrikus, Rutt 2003. Eesti elulugude kogu ja selle uurimise perspektiive. In: Krikmann, Arvo; Olesk, Sirje (eds.), Võim ja kultuur. Tartu: Eesti Kirjandusmuuseum, Eesti kultuuriloo ja folkloristika keskus, 171-213.

Hinrikus, Rutt; Kõresaar, Ene 2004. A brief overview of life history collection and research in Estonia. In: Kirss et al. 2004: 19-34.

Ivanova, T. G. 1994. Russkaya folkloristika v nachale XX veka. Zhivaya starina 1: $27-30$

Jaago, Tiiu; Jaago, Kalev 1996. “See olevat olnud....” Rahvaluulekeskne uurimus esivanemate lugudest. [Eine Untersuchung über die Familienüberlieferung vom folkloristischen Gesichtspunkt aus betrachtet.] Tartu: Tartu Ülikooli Kirjastus.

Jaago, Tiiu 2002. Popular history in the view of Estonian folkloristics: From the question 'Thru or false' to the question 'What kind of truth'. In: Jaago, Tiiu; Kõiva, Mare; Kärsna, Kairiki (eds.), Lives, Histories and Identities III. Studies on Oral Histories, Life- and Family Stories. Tartu: University of Tartu, Estonian Literary Museum, 390-404.

- 2004. Narrationen von Heimat und Abstammung: Esten und ethnische Minoritäten in Estland erzählen. In: Wienker-Piepho, Sabine; Roth, Klaus (eds.), Erzählen zwischen den Kulturen. (Münchener Beiträge zur Interkulturellen Kommunikation, 17.) Münster: Waxmann, 172-185. 
- 2005. Jakob Hurt: The birth of Estonian-language folklore research. In: Jaago, Tiiu; Kuutma, Kristin (eds.), Studies in Estonian Folkloristics and Ethnology. A Reader and Reflexive History. Tartu: Tartu University Press, 45-64.

Kirss, Tiina; Kõresaar, Ene; Lauristin, Marju (eds.) 2004. She Who Remembers Survives: Interpreting Estonian Women's Post-Soviet Life Stories. Tartu: Tartu University Press.

Kreutzwald, Friedrich Reinhold 1844. Nochmals eine Erklärung über die Labyrinth-Frage. Das Inland. Eine Wochenschrift für Liv-, Esth- und Curlands Geschichte, Geographie, Statistik und Literatur 9(41): 645-658.

Kõresaar, Ene 2005. Elu ideoloogiad. Kollektiivne mälu ja autobiograafiline minevikutõlgendus eestlaste elulugudes. [Ideologies of Life. Collective Memory and Autobiographical Meaning-Making of the Past in Estonian PostSoviet Life Stories.] Tartu: Eesti Rahva Muuseum.

Mandel, Mati 2005. Suvi 1941 Kirblas. [Summer 1941 in Kirbla.] In: Läänemaa Muuseumi Toimetised 9. Haapsalu: Läänemaa Muuseum, 7-35.

Nekljudov, Sergei 1998. Istoricheskij narrativ: mezhdu "realnoj dejstvitelnostyu" i folklornoj mifologicheskoj shemoj. In: Bogdanov, K.; Panchenko, Aleksandr (eds.), Mifologia i povsednevnost. Sankt-Peterburg: Institut russkoj literatury (Pushkinskij dom), otdel folklora, 288-292.

Õispuu, Leo (ed.) 1996, 1998, 2005. Political arrests in Estonia under Soviet occupation. Nõukogude okupatsioonivõimu poliitilised arreteerimised Eestis. Vols. 1, 2, 3. (Repressed persons records: Books 1-3.) Tallinn: Eesti Represseeritute Registri Büroo.

Õispuu, Leo (ed.) 1999, 2003. Deportation from Estonia to Russia: deportation in March 1949. Kü̈̈ditamine Eestist Venemaale: märtsiküüditamine 1949. Vols. 1, 2. (Repressed persons records: Books 4-5.) Tallinn: Eesti Represseeritute Registri Büroo.

Portelli, Alessandro 1997. The Battle of Valle Giulia: Oral History and the Art of Dialogue. Madison: The University of Wisconsin Press.

- 2000. What makes oral history different. In: Perks, Robert; Thomson, Alistar (eds.), The Oral History Reader. London: Routledge, 63-74.

Rahi-Tamm, Aigi 2004. Teise maailmasõja järgsed massirepressioonid Eestis: allikad ja uurimisseis. (Dissertationes Historiae Universitatis Tartuensis 9.) Tartu: Tartu Ülikooli Kirjastus.

Rüütel, Ingrid 1977. 1877.-1878.a. Vene-Türgi sõda eesti laulutraditsioonis. Keel ja Kirjandus 8: 481-488; 9: 550-555.

Tampere, Herbert 1970. Revolutsioon ja rahvalaul. In: Tampere, Herbert (ed.), "Priiusel' raiume rada..." Artiklite kogumik eesti revolutsioonilauludest. Tallinn: Eesti Raamat, 217-281

Thompson, Paul 2000. The Voice of the Past. Oral History. New York: Oxford University Press.

Tulving, Endel 1994. Mälu. Tallinn: Kupar. 


\section{Критические события 1940-х годов \\ в эстонских жизнеописаниях}

В статье рассматривается, каким образом критические времена, связанные с приходом Советской власти и Второй мировой войной, отражались в жизнеописаниях, написанных во вновь независимой Эстонии. Анализ устных рассказов сравнивает тексты из южной части Läänemaa (интервью проведены в 2005 году), матерьялом для анализа написанных историй послужили ответы на вопросник Эстонского национального музея и жизнеописания, собранные в сборнике «Сто жизнеописаний века» (1999). Исторический контекст был почерпнут из матерьялов Эстонского исторического архива и архива уезда Läänemaa.

Исследование сфокусировано на двух главных вопросах. Первый: различаются ли устные и письменные нарративы только по форме, или они имеют и разное содержание (разные идеологии). Второй: воспоминания и исторические документы только дополняют другдруга, или они меняют наши представления о случившемся. Нарративы представлены с определенной точки зрения, следуя убеждениям рассказчика, при этом главное сообщение остается тем же в разных презентациях. Рассказы основаны на опыте о том, как люди справлялись (как на практическом так и на ментальном уровнях) в трудных условиях. Конфликта между историческими источниками и воспоминаниями не наблюдается, но добавление исторических источников позволяет лучше прослеживать развертывание нарративной традиции (нарративные правила) и высвечивать новые вопросы (скрытые в нарративе).

\section{0. aastate kriitilised sündmused eesti elulugudes}

Artiklis vaadeldakse, kuidas praegu, taasiseseisvunud Eestis kirjutatud elulugudes kajastuvad kriitilised ajad, mille tingisid Nõukogude võimu kehtestamise ja Teise maailmasõjaga kaasnenud sündmused (sõjaolukord, okupatsioonid, massirepressioonid). Pärimusliku ajaloo vaatepunktist analüüsitakse tekste Lõuna-Läänemaalt: suuline eluloointervjuu (2005), kirjalikud vastused Eesti Rahva Muuseumi küsitlusele "1949. aasta küüditamine, elu asumisel" (1999) ja vaba struktuuriga kirjalik eluloojutustus, mis on saadetud Eesti Kirjandusmuuseumi elulugude kogumisvõistlusele "Sajandi sada elulugu" (1999). Ajaloolise konteksti loomiseks on kasutatud materjale Eesti Ajalooarhiivist ja Lääne Maa-arhiivist. 
Käsitluses on kesksed kaks küsimust. Esmalt, kas suulised ja kirjalikud jutustused erinevad vaid esitusviisi poolest või kannavad need endas ka erinevaid sõnumeid (ideoloogiaid). Teiseks, kas mälestused ja ajaloodokumendid ainult täiendavad üksteist või muudavad nad olemuslikult ka sündmustest saadavaid ettekujutusi. Avalikkusele esitatakse kogemusjutustused, kuidas rasketes oludes hakkama saadi, seda nii praktilisel kui ka mentaalsel tasandil. Lood esitatakse teatud vaatepunktist jutustajate veendumuste kohaselt, mistõttu lugude põhisõnum jääb erinevates esitustes samaks. Konflikti ajalooallikate ja mälestuste vahel esile ei tulnud. Küll aga võimaldab ajalooallikate lisamine mälestuste uurimisse paremini jälgida jututraditsiooni kujunemist (jutustamisreegelid) ja esile tuua uusi (loos varju jäävaid) küsimusi. 